\title{
Necrotic patches affect Acropora palmata (Scleractinia: Acroporidae) in the Mexican Caribbean
}

\author{
R. E. Rodríguez-Martínez*, A. T. Banaszak, E. Jordán-Dahlgren \\ Instituto de Ciencias del Mar y Limnología, UNAM Apartado Postal 1152, 77500 Cancún, Q Roo, México
}

\begin{abstract}
An outbreak of necrotic patches was observed affecting Acropora palmata in the Mexican Caribbean in the summer of 1999. This study documents the tissue loss produced by these patches. Following a marked initial increase in the number of patches, there was a decrease in the appearance of new patches but the size of the patches increased throughout the study. In some cases patches expanded but in most cases they enlarged due to fusion of 2 or more patches. Patches recovered but not sufficiently to overcome damage in most colonies surveyed. Percentage tissue loss does not appear to be directly related to temperature but may be related to a combination of factors associated with prolonged summer doldrum-like conditions. The necrotic patch syndrome can have a substantial impact in tissue loss in affected A. palmata colonies.
\end{abstract}

KEY WORDS: Coral diseases $\cdot$ Patchy necrosis $\cdot$ Acropora palmata $\cdot$ Mexican Caribbean

Resale or republication not permitted without written consent of the publisher -

\section{INTRODUCTION}

Acropora palmata (Lamarck, 1816) is the dominant reef-building coral in many Caribbean reefs at depths of 1 to $5 \mathrm{~m}$ (Gladfelter 1982), whose numbers have been drastically reduced in recent decades due to hurricanes, diseases and unknown agents (Harvell et al. 1999).

An outbreak of an undiagnosed coral disease was observed affecting Acropora palmata in Puerto Morelos reef, Quintana Roo, Mexico, in the summer of 1999. It was characterized by irregularly shaped necrotic patches distributed predominantly on the upper surface of colonies (Fig. 1), surrounded by living tissue with a normal appearance. It is difficult to determine whether this patchy necrosis has been described previously because of the informal classification of coral diseases. Although a number of hard-coral diseases have been named, particularly in the popular literature, only two of these diseases (black band disease and plague type II) have causative agents identified formally, after

*E-mail: rosaer@mar.icmyl.unam.mx satisfying Koch's postulates (Richardson 1998). Richardson (1998) has suggested that in the absence of formal identification of a causative agent a 'disease' should be called a syndrome or potential disease state. The visible symptoms of the necrotic patches we observed are similar to the 'patchy necrosis' observed by Bruckner \& Bruckner (1997) in Puerto Rico and to the so-called 'white pox disease', first observed affecting A. palmata colonies in the Florida Keys around 1995 (Goreau et al. 1998, see also McCarty \& Peters ${ }^{1}$ ). A. palmata colonies with similar symptoms have also been observed in the Bahamas (E. Peters pers. comm.), the Virgin Islands and San Salvador (G. Smith pers. comm. ${ }^{2}$ ).

Our observations show that the patches enlarge radially by necrosis at the boundary of the living coral

\footnotetext{
${ }^{1}$ The coral disease page. http://ourworld.compuserve.com/ homepages/mccarty_and_peters/coraldis.htm

${ }^{2}$ In his plenary address at the 30th meeting of the Association of Marine Laboratories of the Caribbean (held June 24-29, 2001, in La Parguera, Puerto Rico), Dr Garriet Smith identified the causative agent of white pox in Acropora palmata as the Eubacterium Serratia sp.
} 

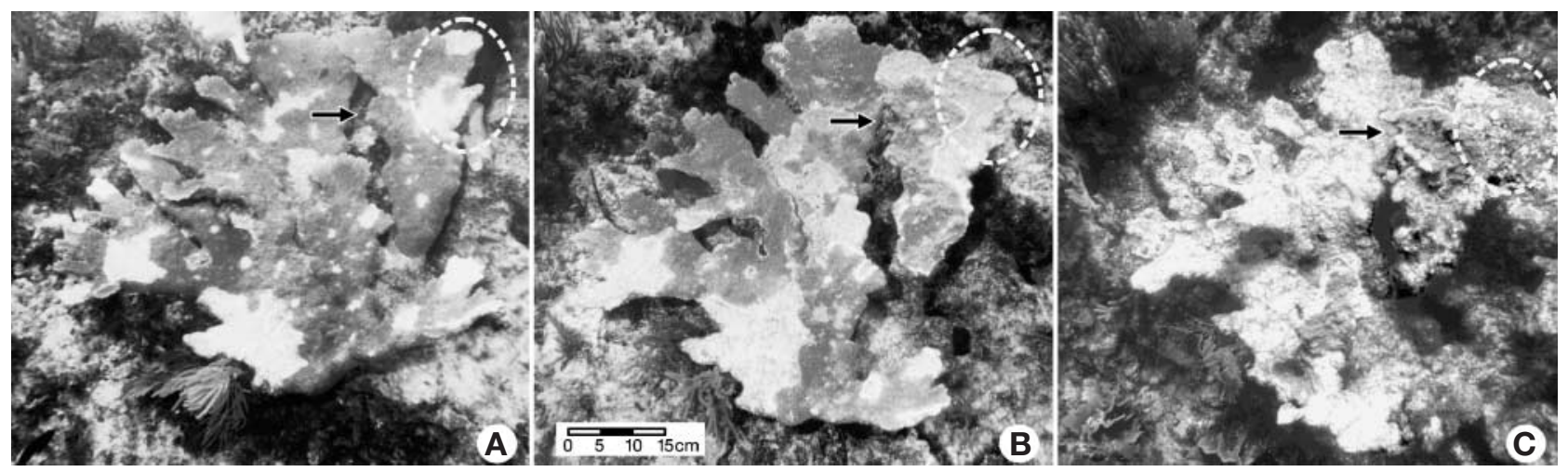

Fig. 1. Acropora palmata colony (\#6) showing progression of necrotic patches, Puerto Morelos reef, Mexico. (A) October 1, 1999; (B) January 26, 2000; and (C) March 8, 2001. White dashed oval is located on a branch that contains 2 necrotic patches (A), which fused (B) and were colonized by algae (C). Black arrows point to tissue that survived throughout the study period

tissue leaving behind a bare but otherwise undamaged skeleton. These necrotic patches usually become colonized by thin turfs of filamentous algae or a thin layer of sediment after a few days and eventually the skeleton shows signs of degradation. The outbreak was first observed on September 2, 1999, and many of the necrotic patches seemed to have formed recently because the exposed skeleton was not covered by sediment, filamentous algae or other fouling organisms. Only Acropora palmata was affected by the patchy necrosis; other coral species on the reef were not injured, although 2 colonies of $A$. prolifera, which is very scarce in the area, were observed with similar symptoms.

During the period of our study, some Acropora palmata colonies with patchy necrosis were also affected by white-band disease. The lesions produced by patchy necrosis start on the upper surface and edges of branches, thus differing from those caused by whiteband disease, which usually starts at the base of the colony and works its way upward (Gladfelter 1982) on both the upper and lower surfaces of the colony.

The purpose of this study was to document the tissue loss produced by necrotic patches on Acropora palmata colonies over time and to obtain information about the progression of this syndrome.

\section{METHODS}

A semi-quantitative sampling design was used during the first observations of the necrotic patch syndrome. Because many colonies exhibited necrotic patches at the time of our first observations, we wanted to determine the general characteristics of this syndrome and needed to design a quantitative protocol with which we could follow the progression of the syndrome. On September 9, 10 colonies of Acropora palmata displaying symptoms of patchy necrosis were tagged in one of the most affected stands on the rear zone of Puerto Morelos reef, Mexico (3 to $4.5 \mathrm{~m}$ depth). Colonies were not randomly chosen but selected by position (i.e., horizontally oriented branches) and ease of photography, and were selected across a depth gradient at the study site. In situ color photographs of the extended upper branches of whole colonies, with a scale and identification tag, were taken in September and October 1999, January, May and August 2000, and March 2001. The camera was held at roughly the same position and orientation at consecutive shooting sessions. The photographs were scanned and the areas of all of the necrotic patches on each colony and total colony areas were calculated, using the software program SigmaScan Pro Version 4.0 (SPSS, Chicago, IL). The areas and progression of 360 necrotic patches were measured during the study period. Each necrotic patch was given an identification number to determine, in successive samplings, whether it recovered, grew, fused or underwent fission. We estimate the precision of the calculations of patch size to be roughly on the order of $\pm 10 \%$, which is enough to follow the progression of the patches semi-quantitatively.

\section{RESULTS}

The percentage colony surface area affected by necrotic patches increased from September 1999 to March 2001 in 9 out of 10 colonies. The patchy necrosis progressed to total live tissue loss in the 2 smallest colonies (Fig. 2). On September 9, 162 necrotic patches were registered in the 10 tagged colonies with the number of necrotic patches per colony varying from 2 to 39 (Table 1) and ranging in area from 0.1 to $623.5 \mathrm{~cm}^{2}$ (mean $\pm \mathrm{SD}: 15.4 \pm 52.9 \mathrm{~cm}^{2}$ ). An estimate of the percentage area of the colonies affected by ne- 


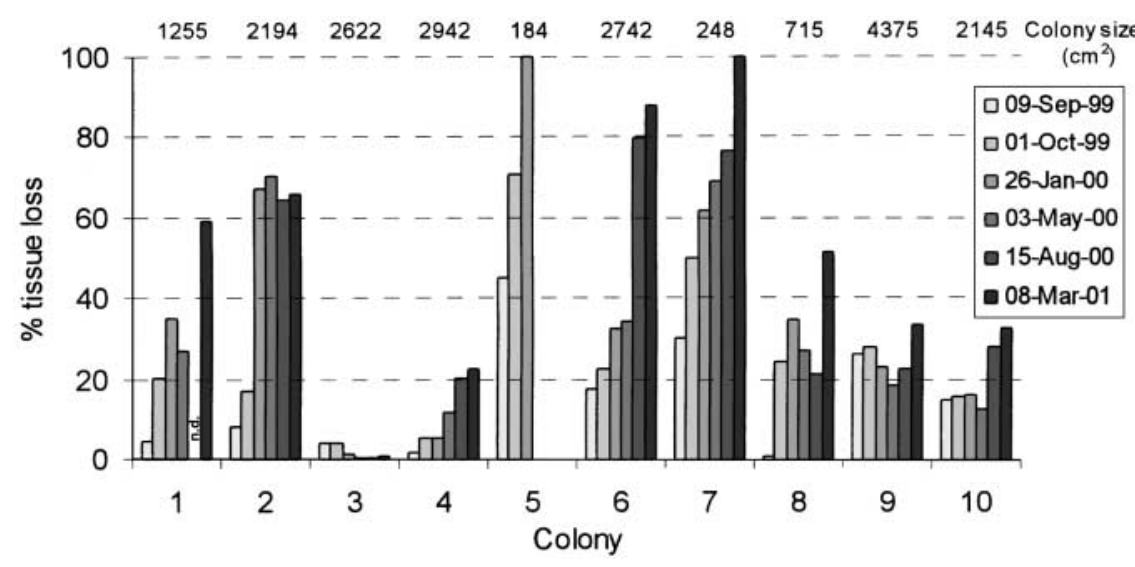

Fig. 2. Tissue loss in Acropora palmata as a percentage of total colony area of the 10 A. palmata colonies surveyed repeatedly in Puerto Morelos reef. The series of bars for each colony corresponds to consecutive dates of surveys, whose order is indicated on the right-hand side of the figure. Colony size $\left(\mathrm{cm}^{2}\right)$ is given for each colony at the top of the figure. n.d.: no data in some cases due to enlargement of patches but mostly due to the fusion of 2 or more patches. The average percentage area of the colonies affected by necrotic patches increased to almost $38 \%$ by January 26, 2000 (Table 1). The greatest recovery of lesions occurred in May 2000 when the average dead area decreased to $30 \%$, but by August 15, 2000 the average dead area increased again to nearly $40 \%$ even though there was not a proportional increase in the number of new patches (Table 1). By March 2001, the average dead area increased to approximately $50 \%$ (Table 1 ) averaging over a 3-fold increase from the start of the survey.

The rate of tissue loss due to necrotic patches was estimated using the first

crotic patches varied from 0.7 to $45 \%$ (Table 1 ; Fig. 2). By October 1, 77 new necrotic patches had appeared in the 10 tagged colonies $\left(0.4 \pm 0.2\right.$ new patches colony ${ }^{-1}$ $\mathrm{d}^{-1}$ ) and the average percentage area of the colonies affected by necrotic patches had increased to almost $26 \%$ (Table 1). The oldest necrotic patches on the monitored colonies were covered by a thin layer of filamentous algae or sediment by October 1 and there was evidence of erosion of the corallites.

Following a marked initial increase in the number of necrotic patches (September to October 1999), there was a decrease in the appearance of new patches (Table 1); however, the size of many lesions continued to increase throughout the observation period (Fig. 3),

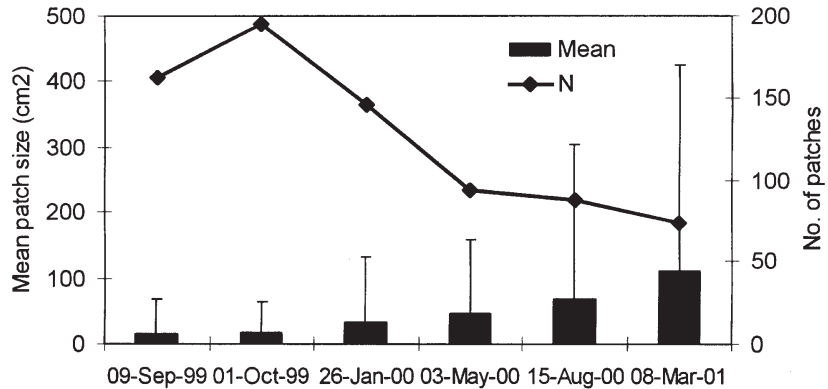

Fig. 3. Acropora palmata mean patch size of necrotic patches (area in $\mathrm{cm}^{2} \pm \mathrm{SD}$ ) and number of necrotic patches in colonies at each sampling period

Table 1. Acropora palmata sample size, number of necrotic patches, percentage of dead area, number of new necrotic patches, number of patches that recovered and number of patches that fused at each sampling period

\begin{tabular}{|llcccccc|}
\hline & & Sep 9, 1999 & Oct 1, 1999 & Jan 26, 2000 & May 3, 2000 Aug 15, 2000 & Mar 8, 2001 \\
\hline No. of colonies & & 10 & 10 & 10 & 9 & 8 & 8 \\
No. of necrotic patches & Total & 162 & 197 & 146 & 93 & 86 & 73 \\
& Mean \pm SD & $16.2 \pm 13.5$ & $19.7 \pm 14.6$ & $14.6 \pm 12.5$ & $10.3 \pm 8.4$ & $10.8 \pm 9.2$ & $8.1 \pm 9.5$ \\
& Range & $2-39$ & $2-46$ & $1-41$ & $1-26$ & $1-30$ & $1-31$ \\
Dead area (\%) & Mean \pm SD & $15.3 \pm 14.6$ & $25.8 \pm 20.4$ & $37.7 \pm 30.5$ & $30.0 \pm 24.5$ & $39.1 \pm 29.9$ & $50.4 \pm 31.7$ \\
& Range & $0.7-45$ & $3.9-70.8$ & $1.5-100$ & $0.4-100$ & $0.4-100$ & $0.4-100$ \\
No. of new patches & Total & 162 & 77 & 52 & 21 & 28 & 20 \\
& Mean \pm SD & $16.2 \pm 13.5$ & $7.7 \pm 5.2$ & $5.2 \pm 7.8$ & $2.3 \pm 2.1$ & $3.5 \pm 2.8$ & $2.2 \pm 2.9$ \\
& Range & $2-39$ & $0-15$ & $0-26$ & $0-6$ & $0-8$ & $0-8$ \\
No. of recovered patches & Total & & 28 & 57 & 63 & 14 & 18 \\
& Mean \pm SD & & $2.8 \pm 4.0$ & $5.7 \pm 5.3$ & $6.3 \pm 6.3$ & $1.6 \pm 2.4$ & $1.8 \pm 2.4$ \\
& Range & & $0-12$ & $0-16$ & $0-21$ & $0-7$ & $0-5$ \\
No. of patches that fused & Total & & 20 & 60 & 17 & 21 & 29 \\
& Mean \pm SD & & $2.0 \pm 2.3$ & $6.0 \pm 8.4$ & $1.7 \pm 3.4$ & $2.3 \pm 5.6$ & $3.2 \pm 2.9$ \\
& Range & & $0-6$ & $0-27$ & $0-11$ & $0-17$ & $0-8$ \\
\hline
\end{tabular}


and last photographs (547 d duration) obtained for each colony. The average rate of tissue loss was estimated to be $1.1 \pm 1.1 \mathrm{~cm}^{2} \mathrm{~d}^{-1}\left(\mathrm{n}=10\right.$, range 0 to $3.4 \mathrm{~cm}^{2}$ $\mathrm{d}^{-1}$ ). This estimation is a very gross approximation because the time elapsed between sampling periods is relatively long and the dynamics of progression are unknown. In 2 cases (Colonies \# 5 and \# 7) earlier photographs were used (140 and 342 d duration, respectively) because the colonies died within the sampling period.

Between September 1999 and March 2001180 patches $(50 \%$ of the 360 monitored during the study period) recovered. Most patches (66.7\%) recovered between January and May 2000 (Table 1). The number of lesions that regenerated between August 2000 and March 2001 was very low compared with those of prior samplings and suggests that the rate of regeneration decreases with time as the size of the lesions increases. Patches that recovered had areas of less than $49.2 \mathrm{~cm}^{2}$ $\left(4.7 \pm 7.0 \mathrm{~cm}^{2}\right)$. Only in 1 colony (\#3) did net recovery exceed net necrosis by the end of the sampling period (Fig. 2). Lesion tissue regenerated when the neighboring living coral tissue grew inwardly, depositing skeletal material. This resulted in a calcified white border tissue where the corallites did not emerge above the coenosteum, and lacked zooxanthellae (endosymbiotic dinoflagellates). The regenerated portions of the colonies remained paler than the neighboring tissue for several weeks and, depending on the size of the lesion, it took from a few weeks to a couple of months for complete recovery of the patch. New lesions sometimes appeared in the same places that had previously been affected and had regenerated. It is possible that some of the smallest lesions were traces of predation by damselfish, which are abundant in the area and are known to cause small lesions on Acropora palmata by biting on the living coral surface (Bak 1983). Because

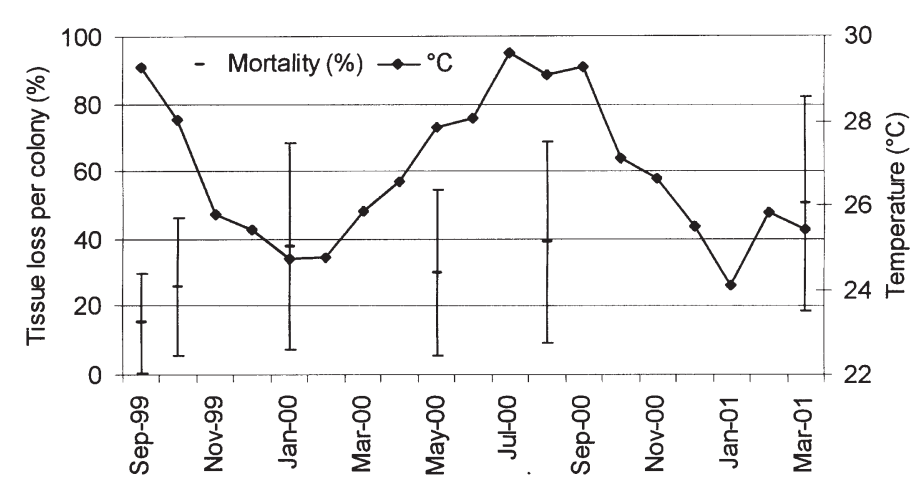

Fig. 4. Acropora palmata mean tissue loss as a percentage of total colony area of $A$. palmata colonies $( \pm \mathrm{SD})$ and monthly average sea surface temperatures sampled daily (approx. 09:00 h) at the Research Station dock in Puerto Morelos, Mexico. CARICOMP (unpubl. data) these lesions were so small $(<1 \mathrm{~cm})$, it was not possible to distinguish them from the necrotic patches in the photographs.

Fusion of necrotic patches was a very common process during the study period and occurred between 2 or several patches. Between September 1999 and March 2001, 147 of the necrotic patches fused with the highest number of fusions registered in January 2000 (Table 1).

Even though the 2 smallest colonies died during the study period (Fig. 2), no definite trends are apparent between percentage tissue loss and colony size, as the response of patches over time was very variable both within and between colonies. Percentage tissue loss does not seem to be directly related to other physicochemical factors, such as temperature (Fig. 4), salinity or the proximity of the colonies to the sandy bottom (data not shown).

\section{DISCUSSION}

Our results indicate that necrotic patch syndrome can have a substantial impact in tissue loss on affected Acropora palmata colonies. Our data, derived from a survey of infected colonies, show both tissue recovery and patch expansion. Apparently, in seriously affected colonies $(>30 \%$ of live tissue loss) the advance of necrotic patch syndrome is more rapid than the recovery from the damage incurred. However, the ecological impact of this syndrome at the population level still remains to be evaluated. Although A. palmata colonies with necrotic patches have been observed on this reef in the past $20 \mathrm{yr}$, the density and widespread distribution observed in 1999 was unprecedented (JordánDahlgren pers. obs.). The proportion of affected colonies seems to vary greatly within a given locality and time of year. While in September 1999 the proportion of diseased colonies fluctuated widely among reef sites, by March 2001 some of these same sites were in better condition.

The causative agent of patchy necrosis has not been identified but preliminary results suggest that bacteria are involved (G. Smith pers. comm.). Bacteria have been isolated from colonies of infected Acropora palmata from geographically diverse reefs, including affected colonies surveyed in this study, and used to successfully re-infect fragments of $A$. palmata; however, genetic sequence analysis of bacterial isolates from all affected colonies needs to be concluded (G. Smith pers. comm.). The mechanism of dispersal of this syndrome is also unknown, and it is common to observe healthy colonies intermixed with affected ones. 
It is possible that in the Acropora palmata system the incidence of necrotic patches was enhanced by the prolonged summer doldrum-like conditions of 1999. The calm seas, clear skies and high water transparency characteristic of these periods result in, among other things, limited gas exchange between corals and the surrounding environment (Jokiel 1978) due to reduced water flow, increased water temperatures and enhanced penetration of UV (280 to $400 \mathrm{~nm}$ ) radiation (Gleason \& Wellington 1993). All of these factors, particularly in combination, are likely to result in an increased stress on coral colonies and can favor the appearance of coral diseases.

Decreased water movement results in a decreased flushing rate between the inner reef lagoon with oceanic water characteristic of the outer reef as well as reduced water motion around individual coral colonies. Flushing removes sediments, moderates extremes in temperature, salinity and dissolved oxygen concentration, and replenishes nutrients (Jokiel 1978). Reduced water motion directly around the coral colonies results in a reduced rate of exchange of gases and substances between the coral tissue and the surrounding sea water (Jokiel 1978) as well as reduced metabolic rates (Patterson et al. 1991, Lesser et al. 1994). Water turbulence has been suggested to limit black band disease activity on the reef-building corals Montastraea annularis and Diploria strigosa (Rützler et al. 1983).

Increased water temperatures have been hypothesized to generate physiological stress in reef-dwelling invertebrates, including corals (Glynn 1991). Elevated temperatures have been shown to impair photosynthesis in the symbiotic alga Symbiodinium microadriaticum in culture and may affect the stability of the symbiotic relation (Iglesias-Prieto et al. 1992) or render the symbiosis more susceptible to disease. Physiological stress may cause symbioses to be less resistant to invasion by other organisms such as algae, bacteria or viruses. Elevated temperatures have been implicated to play an integral role in other scleractinian coral diseases. A significant increase in black band disease was associated with warm water periods in Montastrea cavernosa and Diploria spp. (Bruckner et al. 1997), and Bruckner \& Bruckner (1997) observed that white plague disease on Diploria labyrinthiformis was less prevalent in the winter months and more in May and June. Although the outbreak of necrotic patches, observed in Acropora palmata in 1999, occurred after 4 mo of elevated seawater temperatures and the onset of the summer doldrums, increased seawater temperature by itself does not seem to account for the outbreak of these patches nor does it account for further tissue loss over the rest of the study period (Fig. 4). In October 1998, only 7 out of a total of 81 A. palmata colonies exhibited necrotic patches in four $100 \mathrm{~m}^{2}$ transects
(CARICOMP unpubl. data) made in Puerto Morelos rear-reef. This survey was conducted 2 mo after the maximum recorded sea surface temperature reached its maximum between 1992 and 2000.

UV radiation may play an important role in the coral reef environment (Glynn 1991), particularly during high light and high water transparency periods such as are characteristic of summer doldrum-like conditions. While there are no studies published on a relation between UV radiation and the appearance of coral diseases or syndromes, UV radiation has been shown to negatively affect survival of coral larvae (Gleason \& Wellington 1995) and photosynthesis, and to impair skeletal growth (Jokiel \& York 1982) and coral reef community structure (Jokiel 1980).

Other factors that may also play an important role in the incidence of coral diseases, such as nutrient input, tourism-related activities and over-fishing, have not been evaluated for the Puerto Morelos reef. However, the village of Puerto Morelos is facing rapid change in land use due to increasing coastal development of the Mexican Caribbean coast, which might have negative consequences for the reef.

Acknowledgements. We acknowledge M. E. Rámos, M. A. Maldonado and G. Jordán for their assistance with the field work, F. Ruíz for the CARICOMP data and P. Blanchon for valuable comments to improve the manuscript.

\section{LITERATURE CITED}

Bak RPM (1983) Neoplasia, regeneration, and growth in the reef-building coral Acropora palmata. Mar Biol 77: 221-227

Bruckner AW, Bruckner RJ (1997) Outbreak of coral disease in Puerto Rico. Coral Reefs 16:260

Bruckner AW, Bruckner RJ, Williams EH Jr (1997) Spread of a black-band disease epizootic through the coral reef system in St. Ann's Bay, Jamaica. Bull Mar Sci 61:919-928

Gladfelter WB (1982) White-band disease in Acropora palmata: implications for the structure and growth of shallow reefs. Bull Mar Sci 32:639-643

Gleason DF, Wellington GM (1993) Ultraviolet radiation and coral bleaching. Nature 365:836-838

Gleason DF, Wellington GM (1995) Variation in UVB sensitivity of planula larvae of the coral Agaricia agaricites along a depth gradient. Mar Biol 123:693-703

Glynn PW (1991) Coral reef bleaching in the 1980s and possible connections with global warming. Trends Ecol Evol 6:175-179

Goreau TJ, Cervino J, Goreau M, Hayes R and 14 others (1998) Rapid spread of diseases in Caribbean coral reefs. Rev Biol Trop 46(Suppl 5):157-171

Harvell CD, Kim K, Burkholder JM, Cowell RR and 9 others (1999) Emerging marine diseases: climate links and anthropogenic factors. Science 285:1505-1510

Iglesias-Prieto R, Matta JL, Robins WA, Trench RK (1992) Photosynthetic response to elevated temperatures in the symbiotic dinoflagellate Symbiodinium microadriaticum in culture. Proc Natl Acad Sci USA 89:10302-10305 
Jokiel PL (1978) Effects of water motion on reef corals. J Exp Mar Biol Ecol 35:87-97

Jokiel PL (1980) Solar ultraviolet radiation and coral reef epifauna. Science 207:1069-1071

Jokiel PL, York RH Jr (1982) Solar ultraviolet photobiology of the reef coral Pocillopora damicornis and symbiotic zooxanthellae. Bull Mar Sci 32:301-315

Lesser MP, Weis VM, Patterson MR, Jokiel PL (1994) Effects of water motion on carbon delivery and productivity in the reef coral Pocillopora damicornis (Linnaeus): diffusion

Editorial responsibility: Albert Sparks,

Seattle, Washington, USA barriers, inorganic carbon limitation, and biochemical plasticity. J Exp Mar Biol Ecol 178:153-179

Patterson MR, Siebens KP, Olson RR (1991) In situ measurements of flow effects on primary production and dark respiration in reef corals. Limnol Oceanogr 36:936-948

Richardson LL (1998) Coral diseases: what is really known? Trends Ecol Evol 13:438-443

Rützler K, Santavy DL, Antonius A (1983) The black band disease of Atlantic reef corals. PSZN I: Mar Ecol 4: 329-358

Submitted: July 27, 2000; Accepted: June 28, 2001

Proofs received from author(s): November 19, 2001 